\title{
Separation of Church and State: A Study of Accra City's Use of Public Buildings and Schools for Religious Services in Ghana
}

\author{
Ishmael D. Norman ${ }^{1,2}$ \\ ${ }^{1}$ The Institute of Security, Disaster and Emergency Studies, Accra, Ghana \\ ${ }^{2}$ School of Public Health, University of Health and Allied Sciences, Ho, Volta Region, Ghana \\ Email: ishmael_norman@yahoo.com
}

Received August $6^{\text {th }}, 2013$; revised September $6^{\text {th }}, 2013$; accepted September $11^{\text {th }}, 2013$

Copyright (C) 2013 Ishmael D. Norman. This is an open access article distributed under the Creative Commons Attribution License, which permits unrestricted use, distribution, and reproduction in any medium, provided the original work is properly cited.

\begin{abstract}
This is a review of the Constitutional provisions on freedom of religion in Ghana and to determine whether the Constitution offers to religious bodies the use of public buildings and schools as places of worship. This study consisted of literature and documentary review of cases, the 1992 Constitution and legal writings from Ghana and other jurisdictions on the issue of separation of Church and State. The legal framework for freedom of religion does not include the commingling of public asset with private religious expressions, which goes against the zoning regulations and public policy on noise pollution and nuisance.
\end{abstract}

Keywords: Separation of Church and State; Use of School Buildings; Use of Public Buildings; Religious Worship; Ghana

\section{Introduction}

The issue of separation of Church and State or the doctrine of "laicite" has confronted many democracies around the world, particularly the United States of America. Separation of Church and State does not negate freedom of religion. It does not disparage the tenets of one's faith as a set of mystical irrationality, but a substantive right worthy of pursuit without pressure or coercion from any one or the State (Carter, 1993).

\section{Separation of Church and State in the West Industrialized Nations}

Laicite, a French word, means separation of religion from political power, which in turn protects religion and thus blocks religious influences on the people, at least in public places. Today, in France, there is not a complete separation of Church and State but rather a rationale accommodation of religious expression consistent with public policy (Beita, 2008; Davidson, 2009).

To illustrate the concept of separation of church and state further, the US Constitution guarantees freedom of religion. This includes freedom from religious observance, school prayer, freedom from reciting the pledge of allegiance and freedom from either the state or federal government using government property or finances in support and promotion of religion (Everson, 1947).

The First Amendment to the US Constitution States that, Congress shall make no law respecting an establishment of religion, or prohibiting the free exercise thereof; or abridging the freedom of speech or of the press; or of the right of the people peaceably to assemble, and to petition the government for redress of grievances.
The basic tenets of separation between Church and State as articulated by the US Constitution and Common law were first enunciated in United States Supreme Court decision contained in the case of Everson v. Board of Education (1947) thus:

1) A State or the federal government cannot set up a Church;

2) Laws cannot be passed to aid one religion at the expense of another;

3) There cannot be a national or State preference for one religion over the others;

4) No one can be restricted from going to a Church of his or her preference;

5) No one can be made to attend a Church or religious service;

6) No one can be punished for professing his religious beliefs or disbeliefs, for Church attendance or non-attendance;

7) No tax no matter how infinitesimal the amount can be levied to support any religious activities or institutions, whatever they may be called, or whatever form they may adopt to teach or practice religion.

The facts of the case were:

The appellant, in his capacity as a district taxpayer, filed suit in a State court challenging the right of the Board of Education to reimburse parents of parochial school students with the cost of transportation to school under a new statute. He contended that the statute violated both the New Jersey and the Federal Constitutions. The court held that the legislature was without power to authorize such payment under the State constitution (132 N. J. L. 98, 39 A. 2d 75). The New Jersey Court of Errors and Appeals reversed, holding that neither the statute nor the resolution passed pursuant to it was in conflict with the State constitution or the provisions of the Federal Constitution in issue (133 N. J. L. 350, 44 A. 2d 333). The case went to the US 
Court on appeal under 28 U. S. C. 344(a), 28 U. S. C. A. 344(a). The only contention there was that the State statute and the resolution, in so far as they authorized reimbursement to parents of children attending parochial schools, violated the Federal Constitution in those two respects. First: They authorized the State to take by taxation the private property of some and bestow it upon others, to be used for their own private purposes. This, it is alleged violates the due process clause of the Fourteenth Amendment. Second: The statute and the resolution forced inhabitants to pay taxes to help support and maintain schools which were dedicated to, and which regularly taught, the Catholic Faith. This was alleged to be a use of State power to support church schools contrary to the prohibition of the First Amendment which the Fourteenth Amendment made applicable to the states.

In 1990, the Supreme Court of the United States of America ruled that the States could mount laws to override religious freedoms if such laws do not specifically target a particular religion and if not to do so would encourage wanton breach of the criminal prohibitions of society in the case of Employment Division, Department of Human Resources of Oregon et al $v$. Alfred Smith (Employment Division v. Smith). Smith is a US Supreme Court case that determined that the state could deny unemployment benefits to a person fired for violating a state prohibition on the use of peyote, even though the use of the drug was part of a religious ritual. That is to say, although the state has the power to tolerate otherwise illegal acts done in pursuit of religious beliefs they are not required to do so. The facts of the Smith case were:

"Alfred Smith and Galen Black were members of the Native American Church and counselors at a private drug rehabilitation clinic. They were both fired because they had ingested peyote, a powerful entheogen, as part of their religious ceremonies as members of the Native American Church. At that time intentional possession of peyote was a crime under Oregon law without an affirmative defense for religious use. The counselors filed a claim for unemployment compensation with the state, which was denied because the reason for their dismissal was deemed work-related misconduct."

At the appeals level, the ruling was reversed the ruling. The Appeals Court held that denying Smith and Black their unemployment benefits for their religious use of peyote violated their right to exercise of their religion.

The Oregon Supreme Court agreed, although it relied not on the fact that peyote use was a crime but on the fact that the state's justification for withholding the benefits was outweighed by the burden imposed on Smith's and Black's exercise of their religion.

The state of Oregon appealed to the U.S. Supreme Court, maintaining the same argument that denying the unemployment benefits was proper because using peyote was a crime.

The US Supreme Court left the Oregon Supreme Court's judgment against the disgruntled employees, and returned the case to the Oregon courts to determine whether or not sacramental use of illegal drugs violated Oregon's state drug laws (485 US 660 (1988)). On remand, the Oregon Supreme Court concluded that while Oregon drug law prohibited the consumption of illegal drugs for sacramental religious uses, this prohibition violated the free exercise clause. The case returned to the US Supreme Court in this new posture. The state asked the US Supreme Court to review this second decision of the Oregon Supreme Court, and it agreed to do so.
The Supreme Court said the state or government could not force an individual to give up his religious rituals on the condition of access to unemployment benefits. The Supreme Court found in Smith that the "First Amendment's protection of the 'free exercise' of religion does not allow a person to use a religious motivation as a reason not to obey generally applicable laws". That is to say, when the conduct in question is "justifiably prohibited by law" the individual cannot profit from such a conduct and claim the protection under the "free exercise" clause of the First Amendment to the US Constitution.

This does not mean to suggest that religious freedoms have been curtailed. Rather, there appears to be more accommodation for State-Church partnership through funding of faith-based programs, where the recipients of services from such funds can choose to go to religious or secular providers. It has also been found that the refusal to allow faith-based organizations to participate in bidding for funding is discriminatory (Durham Jr., 2008).

\section{Separation between Church and School in Ghana}

There is often the confusion in Ghana and elsewhere that once a prayer is said at State and official functions, or when the word "God" is mentioned in an oath of allegiance for high office jobs, and then such acts support the position that there is no separation between the State and Church (Mahmood, 2008).

In terms of prayer at public events, it is often not important to those who use it to support the argument that there is no separation between Church and State to verify whether or not the audience are indeed praying or just merely being civil by not protesting, walking out of the hall but being present and rather "tune out and tune in" to, perhaps, more prurient matters. In the case of an oath of allegiance, it appears so few a citizen swears it that its value as evidence of the lack of separation between Church and State is insignificant to the debate and the Constitutional protections for the bulk of the population.

In Ghana, religious bodies use as places of worship, government School buildings and other movable assets or interests of Schools for their exclusive benefits. Although there are a few instances of Schools being temporarily used as prayer centers by religious bodies, the overwhelming majority of the religious groups that adopt Schools as Churches do so for years on end. The question that remains to be asked is, are Churches in Ghana so vulnerable that the state has to carve out special protections for them?

The doctrine of Parens Patriae maintains that the sovereign State power should be exercised with tenderness and respect towards those citizens who are not able to care for themselves, including children, people with physical, mental and other disabilities, and racial and sexual minorities. That is to say, the State is the supreme "parent" of all children and therefore must be given equal protection regardless of faith or creed. Although there is no empirical study in Ghana about the financial status of Churches and other religions, it is generally believed that in most neighborhoods with Churches, Mosques and other religious properties, these tend to be more opulent, if not spectacular in comparison to the houses in the same neighborhoods. There is therefore the inference that the Churches, Mosques and other religious groups are not financially hurting for cash and are capable of building branch churches and mosques or synagogues without resulting to the use of School buildings.

Children at the School going age in Ghana are not only from 
Christian families but they come also from Muslim, Atheist and Traditional religious backgrounds and groupings. When State property supports one religious group, it goes against both the tax-burden and Constitutional interests of those children of a School or Schools so affected, and those of their parents as well (Murray, 1947; Paulsen, 1986).

Others have argued that State sponsored support of churches appear unpatriotic, to the extent that it undermines the development of democracy and individual freedom from religious observance (Paulsen, 1986). At the center of the doctrine of separation of Church and State is that, the State would not either covertly or overtly support or promote one religion at the expense of another. According to a report filed by John Bingham of the "Telegraph" on 10:2:2012, a High Court in London, UK, ruled that there was "no lawful" place for prayer during formal local government proceedings' and that the council had "no power" to include prayers in meetings' under that country's Local Government Act of 1972.

The essential question is: Does the doctrine of separation of Church and State also mean separation of Church and School?

Borrowing from other common law jurisdictions, the case of Everson v. Board of Education provides the continuum for the discussion of the concept of separation of church and state. In Arch R. Everson v. Board of Education of the Township of Ewing et al., it was held that the State is under duty to ignore the child's creed but not its need... The State which allows the pupil to subscribe to any religious creed should not, because of his exercise of this right, proscribe him from benefits common to all. The background to Everson was:

A New Jersey law authorized payment by local school boards of the costs of transportation to and from schools-including private schools of which 96\% were parochial Catholic schools. Arch R. Everson, a taxpayer in Ewing Township, filed a lawsuit alleging that this indirect aid to religion through the mechanism of reimbursing parents and students for costs incurred as a result of attending religious schools violated both the New Jersey state constitution and the First Amendment. After a loss in the New Jersey Court of Errors and Appeals, then the state's highest court, Everson appealed to the US Supreme Court on purely federal constitutional grounds. Arguments were heard on November 20, 1946.

In People of State of Illinois ex rel. Vashti McCollum v. Board of Education of School District No. 71, Champaign County, Illonis et al. the U. S. Supreme court affirmed the earlier precedents on separation of church and state. The facts of the cases were:

Vashti McCollum, the mother of a student enrolled in the Champaign public school district. In 1940, interested members of various Protestant, Catholic, and Jewish faiths formed an association named the Champaign Council on Religious Education. This association obtained permission from the Champaign Board of Education to offer voluntary religious education classes for public school students from grades four to nine. These weekly 30- and 45-minute classes were led by clergy and lay members of the association in public school classrooms during school hours. McCollum, an atheist, objected to the religious classes, stating that her son James was ostracized for not attending them. After complaints to school officials to stop offering these classes went unheeded, McCollum sued the school board in July 1945, stating that the religious instruction in the public schools violated the Establishment Clause of the First Amendment-the principle of separation of church and state in the United States. McCollum also complained that the school district's religious education classes violated the Equal Protection Clause of the Fourteenth Amendment. The principal elements of the McCollum complaint were that:

1) In actual practice certain Protestant groups exercised an advantage over other Protestant denominations.

2) The school district's calling the classes "voluntary" was in name only because school officials coerced or forced students' participation.

3) The power exercised by the Champaign Council on Religious Education in its selection of instructors, and the school superintendent's oversight of these instructors served to determine which religious faiths participated in the instructional program, and constituted a prior censorship of religion.

McCollum asked that the Board of Education be ordered to "adopt and enforce rules and regulations prohibiting all instruction in and teaching of all religious education in all public schools in Champaign District Number 71, and in all public school houses and buildings in said district when occupied by public schools".

In other jurisdictions in the United States of America such as Louisiana, the response to whether or not a School can be used as a Church has been stated thus:

"The use of School facilities, except for educational, governmental, and civil defense and civil emergency purposes, shall be on a temporary, short-term basis. 'Temporary, short-term' is defined as use of School buildings no more than six times in a 12-month period. Use of School facilities for athletic activities only may be permitted on a more frequent basis with the permission of the superintendent of Schools" (Peoples, 2011).

"The Calcasieu Parish School Board policy was designed to give priority to student based organizations and is not meant to show prejudice against Churches”.

\section{The Position of Ghana's 1992 Constitution}

The 1992 Constitution of Ghana is silent on the issue of separation of Church and State. However, a careful reading of the Constitution would show that separation of Church and State is implicit in the Constitutional grant of the freedom of religion. The Constitution provides for the unfettered freedom of religion and freedom of association. Article 17 (2) of the 1992 Constitution of Ghana prohibits discrimination on the grounds of religion and creed. Article 21 (c) to (e) promotes freedom to practice any religion and freedom of association, including religious fellowship. This goes without saying that it also promotes the freedom of disbelief in a religion and non-attendance of Church and religious activities. Articles 18 with 20 and others promote, support and protect the right to own property. This is buttressed by Articles 24, the right to gainful employment in order to earn income in order to invest in property and others including building a Church. Article 25 promotes the right to establish and maintain a private School or Schools, including religious groups that may want to build Schools. Article 26 lends support to the right to enjoy one's religion, promote any culture, language or tradition so long as it is consistent with public policy: the promotion of individual liberties in a free and democratic society. Such rights are co-extensive to both natural persons and other entities.

Every single one of the above provisions exists to promote individual liberties to freedom, right of association and the exploitation of the gains from one's industry. It does not however 
provide that citizens may depend on the government and public assets for their religious expressions or observance (Engel v. Vitale, 1962; Paulsen, 1986).

\section{The Role of the Modern State and Church}

There have been arguments against the strict division between the State and the Church. It has been alleged that "the modern State does not enjoy a monopoly of the citizen's allegiance as did the kings of yesterday. The State shares this allegiance with organized religion or the Church” (Nsereko, 1986). It is generally accepted that "a government that declares itself to be operating on Christian principles effectively undercuts certain potential opposition. Political figures who invoke the name and sometimes the authority of God, even if their lives and actions seem to contradict the workings of God's grace, can have their persuasive power multiplied among Christians who accept their words at face value" (Feldman, 2005; Lambert, 2005; Hamilton, 2002; Berman, 1983).

Haynes (2004) presented in his paper, "Religion and Democracy in Africa" that religion is almost a form of anti-establishment protest against dictatorial government, perhaps. He, however, maintained that to look at religion strictly on such lines would be limiting. His approach was to develop twoprong foci to look at, first, the relationship of senior religious figures to the State and the role of the former in Africa's democratization.

Secondly, he looked at the political importance of "popular" religions in Africa. Haynes's approach, it seems, falters because there is nothing called popular religions in Africa. Each region has its own popular religion and each nation has its own popular religion. A recent survey conducted by the Pew Forum in 2010 concluded that Sub-Sahara Africa is the most religious place on earth, where $98 \%$ of Senegalese and $93 \%$ of Mali said religion is very important to them. In the US, the most religious industrialized nation, only 57\% reported that religion was most important to them (Pew-Templeton Global Religious Futures Project, 2010). Currently, the religious piety that is sweeping through Ghana and the rest of Africa is not essentially different from the so-called "First Great Awakening". This was a period of revitalization of religious piety that took hold of the then American colonies between 1730's and 1770's (Heyman, 2008). The "First Great Awakening" was led then in the American colonies by Protestants. Those Churches promised the population in the new lands, fellowship, solace and group support, when faced with all types of socio-economic challenges, including migration; attacks from indigenous Indians and disease. Today in Ghana, the driving forces behind the revitalization of religion, is similar to the socio-economic push factors that led to the First Great Awakening in the American colonies in the 1770 's. Segments of the population of Ghana continually find their fortunes being squandered away by their political leaders.

There is a permanent State of crisis (van de Walle, 2001; Bates, 1993). They are confronted with both communicable and non-communicable diseases (Ghana Health Service Annual Report, 2010). Many of the population of Ghana are marginalized, devoid of many of the indicators for social determinants of life such as basic housing with potable water and in-door plumbing, good income, access to education, gender equity, freedom of association, and due process. Charismatic and Pentecostal preachers promise the marginalized, prosperity and a better life in the face of crushing difficulties (Hayman, 2008). Religion in
Africa is, therefore, a form of fellowship and worship of a deity and often has nothing to do with political protest.

Political activists tend to co-opt religious bodies into their causes both for the sheer numbers of Church memberships and for emotional support and identity (Bates, 1993). Nsereko's claim that religious bodies are a disguised political force in waiting, which shares the political power with elected political leaders, runs counter to Ghana's Constitutional position on the role of the Church. It is also archaic. Common-law decisions involving Churches and Church interests in Ghana have not chipped away the Constitutional barriers between Church and State in Ghana.

It appears the import of Articles 17 (2) and 21 (c) to (e) is to stop Churches and other religious bodies from claiming authority in national government and thus erecting a wall between the functions of the State and those of the Church (Greenhouse, 2005; Nsereko, 1986). The separation of Church and State divide as pertains in the United States of America includes not only the Church-State divide itself. It is also a legal doctrine that concerns the modern structure of society and government, the rule of law and individual liberties, autonomy, and political legitimacy. Ghanaian society like the society in the United States of America is not governed by ecclesiastical and religious laws, such as Shar-ia law and religious leaders. Ghana has a unitary, unicameral secular government.

The sovereign power of the nation emanates from the people of Ghana and not from the government or religious bodies and Churches (Ghana's Constitution, 1992). The society in Ghana is driven by secular aspirations and idiosyncratic economic and social motives of individuals and those of their respective families and not by directives from the Church and religious bodies or even the government. The society is the driving force pushing the development agenda with government as the driver hired for a 4-year term to give material expression to the goals of the people. There are three main religions in Ghana, namely Christianity which represents $50 \%$ of the population, followed by Muslim with $14 \%$ and Traditional religion has 22\% (Ghana Census Bureau, Statistical Service, 2011). None of such religions can lay claim as essential parts of governance under the current Constitutional dispensation. The essential parts of the government consist of the executive, the parliament and the judiciary. The influence of many of Ghana's Churches is felt by their members, by and large and, perhaps, but by no other entity due to the parochial appeal of many of Ghana's Churches. Churches exist as clubs, deliberative and civic associations but are not the earthly representatives of the moral majority (Weber, 1958; Greenhouse, 2005). In terms of an overarching moral philosophy of the nation, there is no shared or collective moral ethic when it comes to religion, work, civic responsibility, commitment and personal or family values. The Ghanaian identifies first with the family, the tribe and finally, the nation.

Today in Ghana, it appears as if religion is used more as a tool for social networking, personal advancement and eminence, rather than as a means to exemplify ecclesiastical objectives. Although religion plays very influential role among the members of a particular group, it appears what pertains is nothing more than elevated religiosity (McFarland, Uecker, \& Regnerus, 2011, Brothers, 1993; Burton, 1992; Butler \& Harper, 1994; Prest \& Keller, 1993). McFarland, Uecker, et al. (2011) defined elevated religiosity as Church attendance and strength of religious identification. 


\section{The Purpose of the Study}

The indiscriminate citing of Churches in Schools and other government buildings in cities, towns and villages in Ghana has created challenges for public health in terms of noise pollution, nuisance, encroachment, environmental degradation due to unsanitary practices and other environmental and tort crimes. The purpose of this study is to review the Constitutional provisions on freedom of religion in Ghana and to determine whether the Constitution offers to religious bodies the use of public buildings and schools as places of worship. In the Greater Accra alone, there are over 466 public schools and over 386 private schools that receive government support either in the form of school feeding program, hiring and retention of teachers and the supply of basic inputs such as text books. Almost all of these schools are under use as centers of religious worship irrespective of their location and proximity to private residential settlements. There have been violent confrontations between Churches and other cultural-religious groups about drumming noise. There have also been many instances where neighbors have confronted Church agents or sued seeking an order to move such worship to more appropriate locations. Such confrontations and litigations defeat the religious purpose of Church attendance and fellowship. There is also no scientific literature within Ghana on the issue. The legal framework both at statute law and the common-law are also silent on the issue. Although separation of Church and State is not mentioned in the Constitution of Ghana, this does not allow the assumption that the right to practice one's religion includes the right to use government offices, other physical assets and public School buildings financed by the tax-payer as Church Houses. Such private uses of public assets are at the exclusion of other non-religious bodies and associations. Such facilities are often not available to other members of the public and to other faiths. Often, such facilities are not available to the students of the very Schools in which the religious groups hold Church services. The students of such Schools are often denied access to use the buildings to conduct remedial classes in preparation for competitive national examinations. This study would provide the baseline public health and legal reasoning for initiating public discourse and attempt to provide the rationale for developing legal framework to address the issues implicated.

\section{Procedure}

In the present study the national laws that are implicated in this assessment were identified. These included the 1992 Constitution, the Local Government Act, and the Ghana Law Reports from 1980 to 2010, as well as other grey literature nationally available. Documentary search on the internet was conducted with themes such as: the separation of church and state, the use of school buildings as churches, abuse of zoning laws by churches, and separation of church and schools. The documentation on separation of church and state and other grey literature were read and analyzed. The result is interpreted and reported in this paper.

\section{Results from the Literature Review}

All over Ghana, Classroom blocks built with revenues from the tax payers by the government are being used as Church houses in the evenings and during the weekends. It appears also that the Local Government Act, 1993 (Act 462) Part IV dealing with licences and Part VIII dealing with revenue mobilization may be implicated. Part IV (77) dealing with licences States:

No person shall undertake or do within a district any of the acts or things mentioned in the Fifth Schedule to this Act without first having taken out from the District Assembly a licence for that purpose and paid the fee required by bye-laws made under this Act.

Section 78 (3) provides penalties for failure to obtain or produce licences, which includes imprisonment. The Fifth Schedule (Section 77) is captioned: Entertainment Licences and states:

Concerts, musical or theatrical performances, video shows, cinemas, fairs, circuses, dances, discotheques and other entertainments to which admission is to be obtained on payment of money or reward, except where the whole proceeds are being devoted to charity.

Additionally, these other laws of the nation may be implicated, Entertainment Duty Act, 1962 (Act 150), Income Tax (Registration of Trade, Business, Profession or Vocation) Law, 1986 (P. N. D. C. L. 174). Part VII dealing with Financial Matters, Section 86 subsections (3) and (4) empowers the district assemblies to collect levies, fees, and licences for activities listed in the Sixth Schedule. Under this schedule, all manner of both formal and informal commercial, artisan and professional activities are levied, including Town Hall and Community Centers. This mandate appears to be further reinforced by the Second Schedule of the Local Government (Urban, Zonal and Town Councils and Unit Committees) (Establishment) Instrument, 1994, LI 1589, pp. 13-14.

\section{Rent Disbursement and Accountability}

The investigation from municipal revenue agents revealed that there is very little accountability with respect to the rate of charges to the religious bodies for the use of such facilities. There is no standard for the remittances of the amounts collected to the national exchequer. When it comes to the abuse of other ordinances in terms of zoning regulations, or meeting fire, health, sanitation and environmental requirements as well as the abetment of noise and other pollution, the list is exhaustive.

\section{The Position of the Ministry of Education on Renting School Buildings for Church Services}

The Ministry of Education does not have an official policy, the study found, on leasing or renting School buildings and other properties to religious groups. The Ministry's practice goes in the opposite direction that School property should not be used for such activities, but this warning largely goes unheeded. There appears to be a tendency on the part of the churches that in doing allegedly God's work, they can simply flaunt the laws of the nation since the end justifies the means.

\section{Prayer, the Pledge of Allegiance and Separation of Church and State}

The study found that, in fact, the framers of the 1992 Constitution of Ghana intended a separation of Church and State, by making any homily to God at official functions, an optional and non-obligatory personal choice. The Second Schedule of Forms of Oaths to the 1992 Constitution, the Presidential Oath States thus: 
I, having been elected to the high office of President of the Republic of Ghana do (in the name of the Almighty God swear) (solemnly affirm) that I will be faithful and true to the Republic of Ghana; that I will at all times preserve, protect and defend the Constitution of the Republic of Ghana; and that I dedicate myself to the service and well-being of the people of the Republic of Ghana and to do right to all manner of persons. I further (solemnly swear) (solemnly affirm) that should I at any time break this oath of office I shall submit myself to the laws of the Republic of Ghana and suffer the penalty for it. (So help me God).

To be administered by the Chief Justice before Parliament.

The encapsulated homilies, "in the name of the Almighty God swear", or "So help me God", further underscores the neutrality of the 1992 Constitution on the issue of the promotion of religion.

\section{The Position of the Procurement Act on Leasing/Renting School Property}

The Public Procurement Act, 2003 (Act 663) is implicated in the renting of School buildings to Churches. The leasing of government buildings and Schools built with tax payers revenues or subvented agencies is captured under Act 663, Part II, Section 14 (1) (a) through (d) that:

"the procurement of goods, works, and services, financed in whole or in part from public funds except where the Minister decides that it is in the national interest to use a different procedure"; shall be in compliance with the law, as well as "the disposal of public stores and equipment".

"Subvented agency" is defined by Act 663 as "an agency set up by Government to provide public service and financed from public funds allocated by Parliament in the annual appropriation". The Act also defines "national interest" to mean " $a$ condition where the nation attaches high value, returns, benefit and consideration to the matter in question”. Although religion is of high national interest, the drafters of the 1992 Constitution or the successive governments have not considered it high enough a priority to provide for its support and promotion through statute law and the judiciary has not provided for it through the common-law. It appears the leasing of government property, at least, if not subjected to the rigors of the Procurement Law, should be made transparent and public as contained in Part VIII of Act 663, Sections 83 through 85.

\section{Licensing Implications of Churches-in-School-Buildings for District Assemblies}

The Local Government Act, 1993 (Act 462) Part IV dealing with licenses and Part VIII dealing with revenue mobilization are implicated. Part IV (77) dealing with licenses States:

No person shall undertake or do within a district any of the acts or things mentioned in the Fifth Schedule to this Act without first having taken out from the District Assembly a license for that purpose and paid the fee required by bye-laws made under this Act.

Section 78(3) provides penalties for failure to obtain or produce licenses, which includes imprisonment. The Fifth Schedule (Section 77) is captioned: Entertainment Licenses and States:

Concerts, musical or theatrical performances, video shows, cinemas, fairs, circuses, dances, discotheques and other entertainments to which admission is to be obtained on payment of money or reward, except where the whole proceeds are being devoted to charity.

Although this paper did not investigate whether or not the proceeds from Church collections are given in whole or part to charitable courses, the general view is that very few Churches give to charity and often these are the more established, orthodox religions. Additionally, these other laws of the nation, the study found, are implicated: Entertainment Duty Act, 1962 (Act 150), Income Tax (Registration of Trade, Business, Profession or Vocation) Law, 1986 (P. N. D. C. L. 174). Part VII dealing with Financial Matters, Section 86 subsections (3) and (4) empowers the district assemblies to collect levies, fees, and licenses for activities listed in the Sixth Schedule. Under this schedule, all manner of both formal and informal commercial, artisan and professional activities are levied, including the use of Town Hall and Community Centers. This mandate is reinforced by the Second Schedule of the Local Government (Urban, Zonal and Town Councils and Unit Committees) (Establishment) Instrument, 1994, LI 1589, pp. 13-14.

\section{Environmental and Health Impact Assessment of Churches-in-School-Buildings}

The study found that the religious groups that use government Schools and other structures for their private religious purposes other than the purposes for which those structures were built, do not seek permit from the Environmental Protection Agency, (EPA). The Environmental Protection Agency Act, 1994 (Act 490) and its Legislative Instrument, LI 1703 for Environmental Assessment Regulations of 1999 require builders, operators and organizers of public facilities such as hotels, hostels, Churches, Schools, and other activities to seek prior approval after having completed its EIA audit before the commencement of the project. The EPA has the mandate to request EIA from Churches-in-School-buildings and other investors, to demand abetments, cause the arrest of the perpetrator after due process and prosecute for conviction or fine or both. Where a building is being put to different uses other than its original intended uses, the same audit is required, in addition to a Health Impact Assessment by the Ghana Health Service. The National Fire Service is also mandated to conduct pre-use inspection of buildings and to clear the facility for such new use. The launching of the National Platform on Disaster Risk Reduction by the National Disaster Management Organization in 2006 and in 2010 under the auspices of the Ministry of Interior and the United Nations International Strategy for Disaster Risk Reduction was to ensure that all public and private projects and mass uses of buildings meet the national legislative framework on health and safety. The EPA Act and the regulations of the National Fire Service, as well as the zoning by-laws of district assemblies are part and parcel of this legal framework, which form part of the common morality of the communities codified under the 1992 Constitution and statute law.

\section{Discussion}

Previously, it was not common to see Churches being ran from Schools and in Schools. There was a clear distinction between government-public property and that of private individuals and entities. However, from about 1981 through 2011, the number of Churches operating from Classrooms and Schools seemingly permanently in the Accra metropolis and its con- 
stituent neighborhoods, as estimated in this study, grew from about 30 to over 3500 respectively. In many suburbs today, there is a "church" in about every $5^{\text {th }}$ house, although the affected private properties were not zoned for purposes other than residential. These new Churches are off-shoots of charismatic and prosperity Churches.

The Constitution of Ghana provides for freedom of religion, freedom not to be compelled to worship or attend religious service. It promotes secularism and seeks for separation of Church and State. The use of School property for religious service seems to be a prohibited activity under the 1992 Constitution of Ghana. There is also no financial accountability by the religious bodies that use school buildings for their services. In order for Ghana to develop a true democratic nation where all shades of beliefs and views are tolerated, it is incumbent upon the central government and other stakeholders to ensure that there is clear line between the goals and aspirations of the secular government and those of private citizens and entities. When religious bodies refuse to respect the laws of the land by their actions, the message to the rest of society is that anything goes. A recent study on religious violence by national researchers, Norman, Aikins and Binka, (2011) found that violence precipitated against victims due to their religious affiliation in Ghana is quite common with a prevalence rate of $29 \%$ in tertiary institutions. The bulk of such violence was committed by those who were 20 years and younger. Such information raises public health concerns with respect to the motivations of the perpetrators against their counterparts. The proliferation of churches in the suburbs and in the neighbourhoods has both increased church attendance and religiosity, but at the same time, there appears to be a growing sense of intolerance. The national media is replete with complaints about noise pollution and harassment by churches. While the goals of a church could be parochial and protective of its members, it is oxymoronic for a church to be so insular as to alienate the very neighbors church goers are entreated to love.

\section{Conclusion}

The constitution of Ghana provides for the freedom of religion and at the same time, also for the freedom of disbelief from religion. It further offers for separation of church and state and finds the unilateral use of state property for the exclusive benefit of a church to be inconsistent with the legal framework on church and state. If churches want to be centers of excellence, then it is their moral and ethical duty to ensure that they first respect the laws of the land before they could have the moral authority to encourage others in society to lead exemplary lives.

\section{REFERENCES}

Bates, R. (1993). The politics of economic policy reform. Journal of African Economies, 2, 419.

Beita, P. B. (2008). French president's religious mixing of riles critics. Christianity today.

Berman, H. J. (1983). Law and revolution. The formation of the western legal tradition. Harvard: Harvard University Press.

Burton, L. A. (1992). Religion and the family. New York: Haworth Press.
Butler, M. A., \& Harper, J. M. (1994). The divine triangle: God in the marital system of religious couples. Family Process, 33, 277-286. http://dx.doi.org/10.1111/j.1545-5300.1994.00277.x

Carter, S. L. (1993). The culture of disbelief: How American law and politics trivialize religious devotion. New York: Basic Books, 328.

Davidson, S. (2009). Victorian abortion law: Overriding the conscience of doctors.

http://www.aadet.com/article/separation_of_church_and_state

Durham Jr., C. W. (2008). State and religion in America: Problems and perspective. Provo, UT: Brigham Young University Law Library. http://www.iclrs.org/

Employment Division v. Smith, 494 US 872 (1990).

Engel v. Vitale, 370 US 421 at 431, 8 L ed 2d 601 at 608 (1962).

Entertainment Duty Act, 1962 (Act 150).

Everson v. Board of Education (1947) 330 US 1 at 15-16, 91 I ed. 711 at 723.

Feldman, N. (2005). Divided by god. Farrar, Straus and Giroux.

Ghana National Census Bureau (2011). Provisional results of the 2010 census. Ghana National Census Bureau, Statistical Service, Ministries, Accra.

GHS Headquarters (2010). Ghana Health Service Annual Report. Ministries, Accra

Hamilton, N. A. (2002). Rebels and renegades: A chronology of social and political dissent in the United States. Cambridge: Cambridge University Press. http://books.google.com

Haynes, J. (2004). Religion and democratization in Africa. Democratization, 11, 66-86.

Heyman, C. L. (2011). The first great awakening. Driving America, National Humanities Center. http://www.nationalhumanitiescenter.org

Income Tax (Registration of Trade, Business, Profession or Vocation) Law, 1986 (P. N. D. C. L. 174)

Lambert, F. (2005). "Introduction". The founding fathers and the place of religion in America. Princeton: Princeton University Press.

Local Government (Urban, Zonal and Town Councils and Unit Committees) (Establishment) Instrument, 1994, LI 1589, 13-14.

Local Government Act, 1993 (Act 462).

Mahmood, T. (2008). State-religious communities relations in India, a scenario of mutual give and take. International Conference on Law and Religion Studies. http://www.iclrs.org/

McCollum v. Board of Education, District 71, 333 US 203 (1948).

McFarland, M. J., Uecker, J. E., \& Regnerus, M. D. (2011). The role of religion in shaping sexual frequency and satisfaction: Evidence from married and unmarried older adults. Journal of Sex Research.

Murray, C. J. (1947). Separation of church and state: True and false concepts. Woodstock Theological Center Library. http://woodstock.georgetown.edu/library/Murray/1947c.htm

Nsereko, D. D. (1986). Religion, the state, and the law in Africa. Journal of Church and State, 28, 269-287.

Paulsen, M. A. (1986). Religion, equality, and the constitution: An equal protection approach to establishment clause adjudication. Notre Dame Law Review, 311-317.

Peoples, V. (2011). Separation of church and school? Southwest Daily News. http://www.sulphurdailynews.com/

The 1992 Constitution of Ghana.

Public Procurement Act, 2003 (Act 663).

Pew-Templeton Global Religious Futures Project (2010).

http://www.huffingtonpost.com/2010/04/15

Prest, L., \& Keller, J. (1993). Journal of Marital and Family Therapy, 19, 137-148. http://dx.doi.org/10.1111/j.1752-0606.1993.tb00973.x

The Public Procurement Act, 2003 (Act 663).

Van de Walle, N. (2001). African economies and the politics of permanent crisis 1979-1999, (Political Economies of Institution and Decisions) 2001. Cambridge: Cambridge University Press. http://dx.doi.org/10.1017/CBO9780511800344 